\title{
Azospirillum brasilense affects the antioxidant activity and leaf pigment content of Urochloa ruziziensis under water stress ${ }^{1}$
}

\author{
Lucas Guilherme Bulegon², Vandeir Francisco Guimarães ${ }^{2}$, Jessica Cristina Urbanski Laureth ${ }^{2}$
}

\section{ABSTRACT}

Water stress leads to the formation of reactive oxygen species, resulting in degradation of leaf pigments and cell death. This study aimed at assessing the oxidative enzyme activity and photosynthetic pigment content in seeds and/or leaves of Urochloa ruziziensis (syn. Brachiaria) inoculated with Azospirillum brasilense under water stress. Assessments of soluble proteins, chlorophylls $a$ and $b$ and carotenoid contents, as well as the activity of superoxide dismutase (SOD), peroxidase (POD) and catalase (CAT) enzymes, were conducted at the beginning of the water stress process and also under severe water stress and during plant rehydration. Seed inoculation showed a reduction in the action of SOD, under water stress, with an increase after rehydration. POD exhibited an activity greater than CAT in all the assessments, but it did not differ statistically under severe water stress. CAT activity increased under severe stress in all treatments, particularly for leaf inoculation. Chlorophyll $a$ was slightly degraded, maintaining the levels of the irrigated control, while the chlorophyll $b$ and carotenoid contents, in plants subjected to leaf inoculation with $A$. brasilense, were higher under water stress. It was concluded that the leaf inoculation of $U$. ruziziensis with $A$. brasilense makes the plant more efficient at removing reactive oxygen species and protecting chlorophyll $a$.

KEY-WORDS: Superoxide dismutase; catalase; peroxidase; chlorophyll; plant growth-promoting bacteria.

\section{INTRODUCTION}

Plants need water for growing and sustaining vital activities. Their metabolism changes under water stress, which is one of the greatest challenges in agriculture, especially for crops predisposed to adverse weather conditions.

The formation of reactive oxygen species in plants occurs in oxygen-dependent processes, such as photosynthesis. However, in plants subjected to environmental stresses, such as drought, the free

\section{RESUMO}

Azospirillum brasilense afeta a atividade antioxidante e o teor de pigmentos foliares de Urochloa ruziziensis sob déficit hídrico

O déficit hídrico leva à formação de espécies reativas de oxigênio, que resultam em degradação de pigmentos foliares e morte celular. Objetivou-se avaliar a atividade de enzimas oxidativas e o teor de pigmentos fotossintéticos em sementes e/ou folhas de Urochloa ruziziensis (syn. Brachiaria) inoculada com Azospirillum brasilense, sob déficit hídrico. As avaliações do teor de proteínas solúveis, clorofilas $a$ e $b$ e carotenoides e da atividade das enzimas superóxido dismutase (SOD), peroxidase (POD) e catalase (CAT) foram realizadas no início do déficit hídrico, no estágio de déficit hídrico severo e na reidratação das plantas. A inoculação das sementes demonstrou redução na ação da SOD sob déficit hídrico, sendo incrementada após a reidratação. A POD apresentou maior atividade que a CAT em todas as avaliações, contudo, não se diferenciou estatisticamente sob déficit severo. A CAT teve atividade aumentada sob déficit severo em todos os tratamentos, com destaque para a inoculação foliar. A clorofila $a$ foi pouco degradada, mantendo os níveis do controle irrigado, enquanto os conteúdos de clorofila $b$ e carotenoides nas plantas inoculadas com A. brasilense via foliar foram superiores, sob déficit hídrico. Conclui-se que a inoculação foliar de $U$. ruziziensis com A. brasilense torna a planta mais eficiente na remoção de espécies reativas de oxigênio e na proteção da clorofila $a$.

PALAVRAS-CHAVE: Superóxido dismutase; catalase; peroxidase; clorofila; bactérias promotoras de crescimento vegetal.

radical formation increases due to stomatal closure. The limited availability of $\mathrm{CO}_{2}$ in chloroplasts increases the formation of the superoxide anion radical $\left(\mathrm{O}_{2}^{\bullet-}\right)$ (Barbosa et al. 2014). This free radical accumulation results from reduced NADPH oxidation, meaning that the electron transferred from ferredoxin to NADP is transferred to molecular oxygen $\left(\mathrm{O}_{2}\right)$, forming $\mathrm{O}_{2}{ }^{\bullet-}($ Ahmad et al. 2008).

Plants have removal mechanisms for these radicals via antioxidants, in a non-enzymatic system, and through an enzymatic system linked to oxidative 
stress (Sharma et al. 2012). The enzymatic system is performed by superoxide dismutase (SOD), the primary enzyme responsible for plant detoxification, whose function is dismutating $\mathrm{O}_{2}{ }^{\bullet}$, transforming it into hydrogen peroxide $\left(\mathrm{H}_{2} \mathrm{O}_{2}\right)$ and $\mathrm{O}_{2}$ (Ahmad et al. 2008). However, $\mathrm{H}_{2} \mathrm{O}_{2}$ is also harmful to plants that have peroxidases (POD) and catalases (CAT) for their degradation. The reactive oxygen species production occurs on a larger scale in peroxisomes and chloroplasts, leading to chlorophyll degradation in plants.

Increased enzyme activity linked to oxidative stress under drought is reported in a wide range of crops, including corn (Talaat et al. 2015), rice (Kumar et al. 2015), wheat (Huseynova 2012), grass of the Cynodon genus (Liu \& Chan 2015) and other $\mathrm{C}_{4}$ plants (Aimar et al. 2014). However, when water stress is severe, the enzyme activity is limited. In Cynodon dactylon, SOD displays high activity after 7 days without irrigation, but becomes limited at 14 days, due to restricted synthesis of the enzyme, caused by water stress (Shi et al. 2012, Liu \& Chan 2015). Thus, treatments that allow the plant to maintain an active detoxification metabolism for a longer period of time are needed to minimize damage and prevent cell death.

Given that the production of reactive oxygen species and maintenance of antioxidative enzyme activity are largely modulated by the plant water content, techniques that improve the plant ability to maximize the use of water could be beneficial. The use of plant growth regulators and growthpromoting bacteria are alternatives to increase water use efficiency, since they promote better root development (Zakikhani et al. 2012). These symbiotic bacteria may also act as signalers, identifying water shortage in advance in the soil, thereby limiting water losses and allowing the maintenance of enzyme activity (Zakikhani et al. 2012, Zhou et al. 2013).

The present study aimed at assessing the oxidative enzyme activity and photosynthetic pigment content in seeds and/or leaves of $U$. ruziziensis (syn. Brachiaria) inoculated with $A$. brasilense, under water stress.

\section{MATERIAL AND METHODS}

The experiment was conducted from February 2 to April 26, 2015, in a greenhouse with an archshaped roof covered with $150 \mu$-thick low-density polyethylene film with UV protection and sides protected by $40 \%$ white shade cloth. The pots used had a nominal capacity of 8.7 liters and contained soil substrate from the horizon A of an eutrophic Oxisol. The soil had a base saturation of $60.2 \%, \mathrm{pH}$ of 5.5, organic matter content of $24.61 \mathrm{~g} \mathrm{dm}^{-3}, \mathrm{P}$ content of $3.08 \mathrm{mg} \mathrm{dm}^{-3}, \mathrm{~K}$ content of $0.28 \mathrm{cmol} \mathrm{dm}^{-3}$ and a natural diazotrophic population of $4 \times 10^{5} \mathrm{CFU} \mathrm{g}^{-1}$ of soil.

A randomized blocks design, with five treatments and four replications, was used. The treatments were: T1: control under water stress; T2: leaf inoculation with $A$. brasilense under water stress; T3: seed inoculation with $A$. brasilense under water stress; T4: seed and leaf inoculation with $A$. brasilense under water stress; T5: irrigated control.

Two seeds of $U$. ruziziensis, with a pure live seed percentage of $60 \%$, were planted per pot. Seeds were inoculated with $A$. brasilense strains AbV5 and AbV6 (commercial product), with a dose of $1 \mathrm{~mL}$ of inoculant $\left(2 \times 10^{8} \mathrm{CFU} \mathrm{mL}^{-1}\right)$ for every 1,000 seeds. After planting, the pots were kept at field capacity and watered daily. Leaf application of both $A$. brasilense strains (AbV5 and AbV6) was performed when the plants were in the early tillering stage ( 15 days after emergence), using a dose of $300 \mathrm{~mL} \mathrm{ha}^{-1}$ of inoculant and spray volume of $300 \mathrm{~L} \mathrm{ha}^{-1}$. A CO $\mathrm{CO}_{2}$ pressurized backpack sprayer, with Magno 11002 ADGA nozzles spaced $0.5 \mathrm{~m}$ apart and constant pressure of $40 \mathrm{kgf} \mathrm{cm}^{-2}$, was used. After applications, the plants were constantly monitored to ensure proper growth, and no mineral nutrients were applied. Once the plants reached the recommended leaf growth for grazing (45 days after planting), water stress was imposed. Irrigation was suspended in the treatments that included water stress and withheld for six days, at which time the plants exhibited a net photosynthetic rate close to zero (conditions monitored daily with a LI-6400XT infrared gas analyzer). Next, the plants were rehydrated until they reached field capacity.

In order to determine the enzyme activity, fresh $U$. ruziziensis leaves $(0.5 \mathrm{~g})$ were collected at predawn at the water stress onset (first day after water restriction), under severe water stress (six days after water restriction) and after rehydration (one day after rehydration). Soluble protein contents were measured using the Bradford assay. SOD activity was determined by the enzymes ability to inhibit superoxide radicals from reducing nitroblue tetrazolium (NBT) (Giannopolitis \& Ries 1977). 
POD activity was measured at $30{ }^{\circ} \mathrm{C}$ by direct spectrophotometry, based on the guaiacol oxidation (Hammerschmidt et al. 1982). CAT activity was determined by monitoring the variation in hydrogen peroxide absorption (Havir \& McHale 1987).

In order to measure leaf pigment contents, leaf segments with fresh mass of $0.5 \mathrm{~g}$ were placed in covered flasks filled with $80 \%$ acetone solution and stored under refrigeration without light for $72 \mathrm{~h}$. Next, spectrophotometer readings were conducted, using $665 \mathrm{~nm}$ for chlorophyll $a$, $649 \mathrm{~nm}$ for chlorophyll $b$ and $480 \mathrm{~nm}$ for carotenoids (Lichtenthaler \& Buschmann 2001).

Statistical analysis was performed at each assessment via the F-test and, when appropriate, means were compared by the Tukey test at $5 \%$, using the Sisvar statistical software.

\section{RESULTS AND DISCUSSION}

The highest soluble protein content at the water stress onset was obtained in seed inoculation with $A$. brasilense, followed by the irrigated control. It is important to underscore that, up to this point, the plants exhibited only the inoculation effects. Under severe water stress, seed inoculation with A. brasilense once again showed the highest soluble protein levels, with no difference between the remaining treatments. It was observed that protein contents tend to increase under drought, likely due to dilution, since the presence of less water in the leaf tissue means that proteins are more concentrated. This is confirmed by the fact that soluble protein contents in the irrigated control remained constant. After rehydration, both controls showed a rise in soluble protein contents, reaching higher means, whereas low soluble protein levels were recorded for inoculation, regardless of the method (Figure 1).

The rise in protein contents under severe water stress and the dilution effect are associated with increased enzyme activity, protecting them from oxidation and degradation. The results obtained in the present study corroborate those found in cowpea grown under saline conditions, in response to increased POD activity (Maia et al. 2012). Previous results from hypocotyls of corn seedlings also indicate that proteins were protected by increased CAT activity (Rosa et al. 2005).

In the assessment of SOD activity, leaf application of $A$. brasilense induced greater activity, followed by the irrigated control (Figure 2). High daytime temperatures (maximum temperature of $37^{\circ} \mathrm{C}$ ) may have led the plant to experience temporary water stress.

Under severe water stress, low SOD activity was observed for seed inoculation, whereas leaf application and leaf and seed inoculation had similar results (Figure 2). The decline in SOD activity, except for combined seed and leaf inoculation of A. brasilense, occurred as a result of the plants limited recovery ability with less water available in the soil. SOD activity decreased as the water shortage in the substrate increased (Campos et al. 2011). This decline is associated with the rise in the $\mathrm{H}_{2} \mathrm{O}_{2}$ concentration, which reduces SOD activity (Gill \& Tuteja 2010).

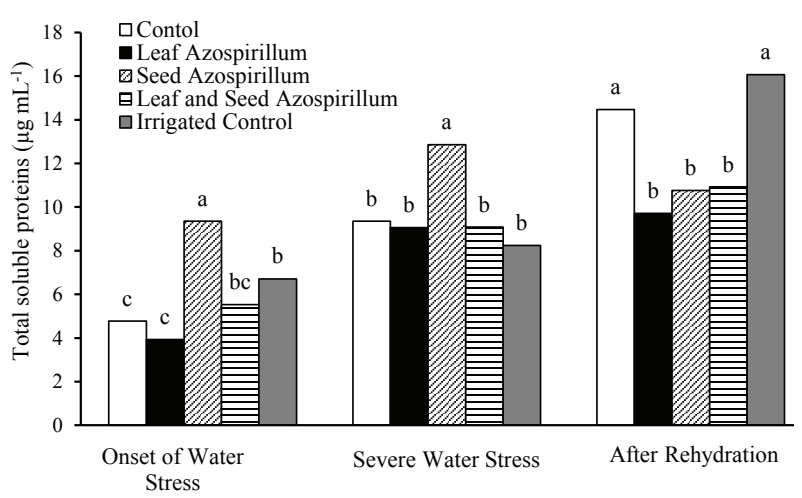

Figure 1. Total soluble protein contents in Urochloa ruziziensis leaves submitted to inoculation with Azospirillum brasilense under water stress. * Different letters indicate a difference between treatments, according to the Tukey test at $5 \%$.

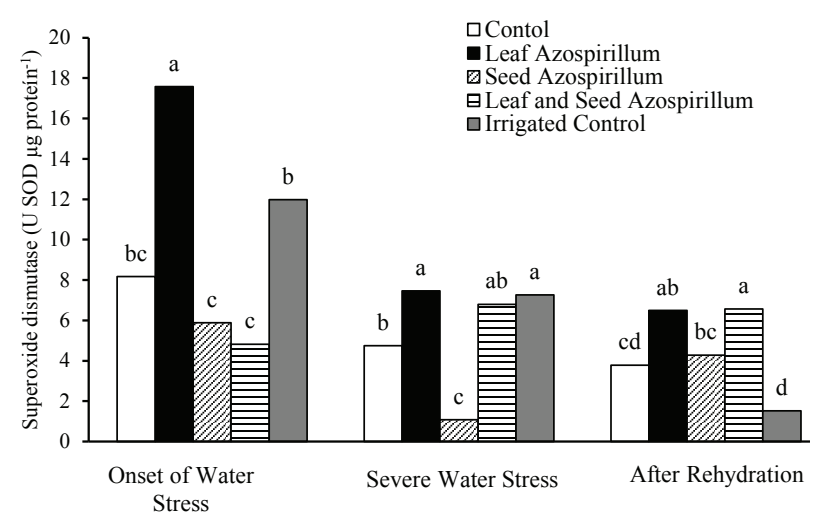

Figure 2. Superoxide dismutase (SOD) activity, in Urochloa ruziziensis leaves submitted to inoculation with Azospirillum brasilense under water stress. * Different letters indicate a difference between treatments, according to the Tukey test at $5 \%$. 
After rehydration, combined seed and leaf inoculation with $A$. brasilense produced the highest SOD activity, with no difference in relation to leaf application. The maintenance of SOD activity levels indicates that the plant is still suffering the effects of water stress, and still eliminating reactive oxygen species. This is a standard response, since plants try to balance their physiological and biochemical systems, what is considered a critical moment, given the stress imposed.

It is important to point out that some of the results observed are difficult to explain, such as the decrease in SOD activity observed in the irrigated control. This is possibly linked to uncontrollable variations, among which stands out the genetic variation inherent of some grasses. Urochloa ruziziensis plants have great genetic variability, which may have led to the inconsistences found between evaluations. Another possible explanation may lie in environmental changes between evaluations.

CAT activity prior to imposed water stress was higher in the leaf application of $A$. brasilense, but differed only from the irrigated control (Figure $3 a$ ). Similar results were recorded under severe water stress and during rehydration, with leaf inoculation exhibiting the highest CAT activity, differing from the combined seed and leaf applications. The lowest CAT activity levels were obtained in the irrigated control.

POD assessment indicated that irrigated control plants initially displayed the lowest activity (Figure 3b). No significant difference was observed for POD activity under severe water stress. After rehydration, control plants maintained under water stress exhibited higher POD activity, with no difference in relation to irrigated controls, which, in turn, did not differ from $A$. brasilense inoculated plants.

The high expression of POD throughout the experiment indicates that this was an important enzyme for the removal of $\mathrm{H}_{2} \mathrm{O}_{2}$ radicals in all the assessment days (Figure 3b). CAT activity was the highest one under severe water stress (Figure 3a), corroborating findings in plants grown under drought stress.

The behavior of these enzymes may be explained by the oxidation mechanism used. POD depends on a reducing agent, such as guaiacol, a phenolic compound whose formation declines under water scarcity. Plants constantly produce reactive oxygen species, and prior to water stress, they occur mainly in the chloroplasts, as a result of photoinhibition, which leads to greater POD activity.

In turn, CAT operates without the need of a reducing agent, resulting in increased activity. As such, this enzyme becomes more important in adverse conditions, such as severe water stress (Esteves \& Suzuki 2008, Barbosa et al. 2014). Another advantage of CAT is its $\mathrm{H}_{2} \mathrm{O}_{2}$ removal ability of approximately 6 million molecules per minute. Moreover, the enzyme acts primarily in peroxisomes (Gill \& Tuteja 2010, Sharma et al. 2012), the main sites of reactive oxygen species formation under severe adverse conditions (Sharma et al. 2012, Barbosa et al. 2014).

Plants tend to recover under rehydration. However, enzyme activity may be maintained low, since recovery is gradual. This is evident in Panicum virgatum, in which a slight variation in enzyme activity was recorded $12 \mathrm{~h}$ after rehydration, increasing after $24 \mathrm{~h}$ (Aimar et al. 2014). A similar behavior has been observed in citrus plants (Campos et al.2011), in which SOD and POD activities showed no variation during the rehydration of Portulaca oleracea for $72 \mathrm{~h}$ (Jin et al. 2015).
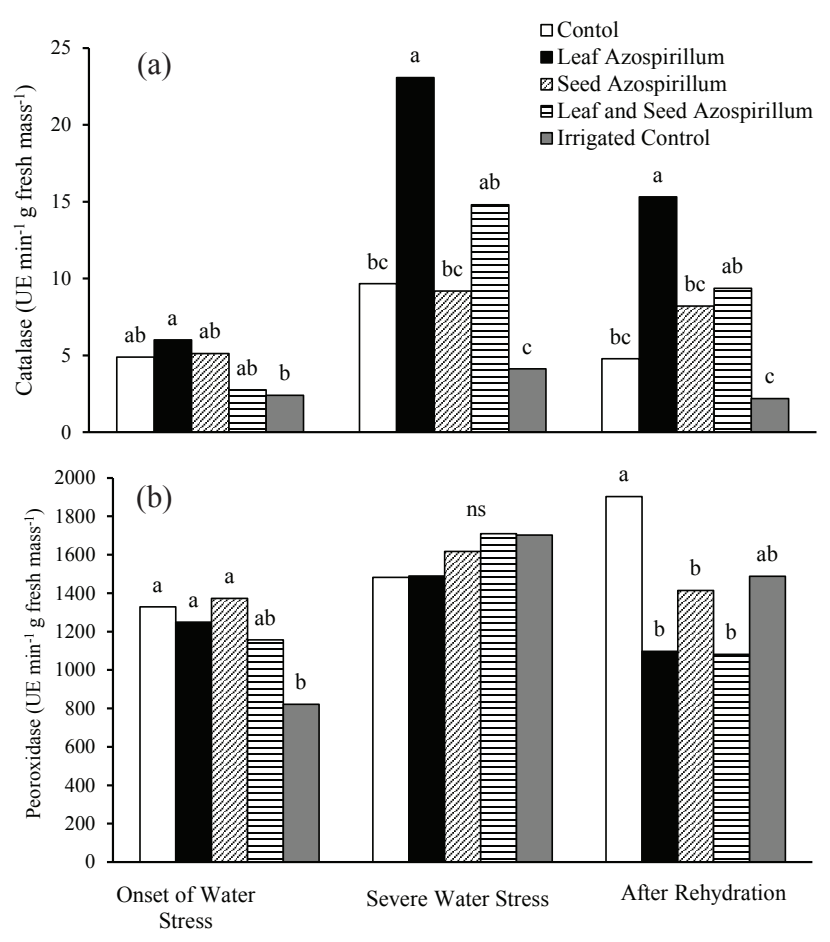

Figure 3. Catalase (a) and peroxidase (b) activity, in Urochloa ruziziensis leaves submitted to inoculation with Azospirillum brasilense under water stress. * Different letters indicate a difference between treatments. ${ }^{\text {ns }}$ not significant, according to the F-test at $5 \%$. 
Thus, an increase in enzyme activity is a drought tolerance mechanism in plants. As such, leaf inoculation with $A$. brasilense may be used to improve the drought tolerance of $U$. ruziziensis, since POD and CAT activities increased under moderate and severe water stress, respectively.

Chlorophyll, found primarily in chloroplasts (Streit et al. 2005), is divided into two types: chlorophyll $a$, responsible for photochemistry, and chlorophyll $b$, which captures light energy (Taiz \& Zeiger 2013). Chlorophyll molecules are predisposed to the action of free radicals formed within chloroplasts (Uzilday et al. 2012).

The assessment of chlorophyll $a$ content in $U$. ruziziensis leaves resulted in no significant intertreatment differences prior to the water stress onset. Under severe water stress, a decline in chlorophyll $a$ levels was observed in the treatment with combined leaf and seed application of $A$. brasilense. No significant inter-treatment variations were recorded after rehydration (Figure 4a). This is related to the increase in oxidative enzyme activity (Figures 2 and 3), which effectively prevented chlorophyll degradation.

Lack of chlorophyll degradation is also reported for $\mathrm{C}_{4}$ plants, such as $U$. ruziziensis (Abdelgawad et al. 2015). Low chlorophyll $a$ degradation under water stress is desirable, because water scarcity inhibits the chlorophyll synthesis (Jin et al. 2015). Thus, plants are dependent on chlorophyll preservation, in order to resume photosynthesis after rehydration. This explains the absence of new chlorophyll synthesis after rehydration (Figures $4 \mathrm{a}$ and $4 \mathrm{~b}$ ), since the plant was still stabilizing its metabolic status and photosynthetic apparatus (data not shown).

The results demonstrate that chlorophyll $a$ was preserved under water stress. This is consistent with the antioxidant enzyme activity and increased carotenoid content observed, which reached maximum levels with the foliar application of A. brasilense. This was the treatment that promoted the greatest protection in this forage crop.

With respect to leaf chlorophyll $b$ content prior to water stress, leaf inoculation with $A$. brasilense showed the highest mean, and no difference in relation to the control. Under severe water stress, seed inoculation resulted in the highest chlorophyll $b$ content, with no difference when compared to leaf application (Figure 4b). Regarding the carotenoid content before water stress, the irrigated control exhibited the highest levels, with no difference in relation to the leaf application of $A$. brasilense. Under severe water stress, leaf inoculation showed the highest mean, whereas seed application obtained the greatest mean after rehydration, with no difference from the irrigated control.

The increase in chlorophyll $b$ under severe water stress for leaf application of $A$. brasilense (Figure 4b) is related to the 'stay-green' effect promoted by inoculation (Quadros et al. 2014). This is also a photoprotective response associated with the increased carotenoid content (Figure 4c). Carotenoids are pigments that sequester $\mathrm{O}_{2}^{-}$, preventing chlorophyll degradation (Gill \& Tuteja 2010).

Our results demonstrate the potential for using the growth-promoting bacteria $A$. brasilense to increase the antioxidant activity in $U$. ruziziensis. However, further research is needed to determine
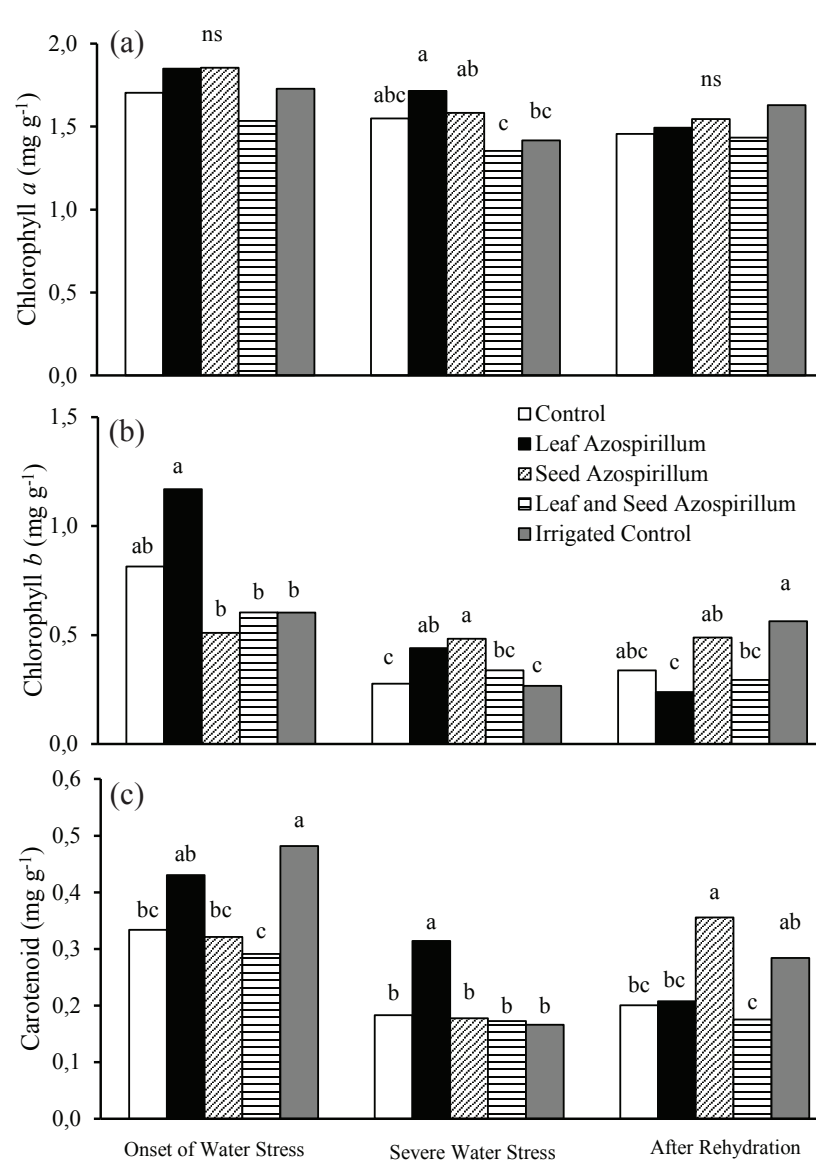

Figure 4. Concentrations of chlorophyll $a$ (a), chlorophyll $b$ (b) and carotenoid (c), in Urochloa ruziziensis leaves submitted to inoculation with Azospirillum brasilense under water stress. * Different letters indicate a difference between treatments. ${ }^{\text {ns }}$ not significant, according to the F-test at $5 \%$. 
which of the bacteria actions interfere directly in this response, since the antioxidant system of plants varies with a series of environmental and ontogenetic factors.

\section{CONCLUSIONS}

1. Leaf inoculation with Azospirillum brasilense is effective in raising SOD and CAT activities under severe water stress;

2. Leaf application of $A$. brasilense increases SOD activity;

3. No decline in chlorophyll $a$ content was observed under water stress.

4. Leaf inoculation with $A$. brasilense exhibited the highest carotenoid and chlorophyll $a$ and $b$ concentrations, and could therefore be used as a management tool for $U$. ruziziensis, during the dry season.

\section{ACKNOWLEDGMENTS}

This study was financially supported by the Coordenação de Aperfeiçoamento de Pessoal de Nível Superior (Capes), Conselho Nacional de Desenvolvimento Científico e Tecnológico (CNPq), Instituto Nacional de Ciência e Tecnologia da Fixação Biológica do Nitrogênio (INCT-FBN), Secretaria de Ciência, Tecnologia e Ensino Superior do Estado do Paraná, Fundação Araucária and Universidade Estadual do Oeste do Paraná.

\section{REFERENCES}

ABDELGAWAD, $\mathrm{H}$. et al. Elevated $\mathrm{CO}_{2}$ mitigates drought and temperature-induced oxidative stress differently in grasses and legumes. Plant Science, v. 231, n. 2, p. 1-10, 2015.

AHMAD, P.; SARWAT, M.; SHARMA, S. Reactive oxygen species, antiocidants and signalin in plants. Journal of Plant Biology, v. 51, n. 3, p. 167-173, 2008.

AIMAR, D. et al. Drought effects on the early development stages of Panicum virgatum L.: cultivar differences. Biomass and Bioenergy, v. 66, n. 6, p. 49-59, 2014.

BARBOSA, M. R. et al. Geração e desintoxicação enzimática de espécies reativas de oxigênio em plantas. Ciência Rural, v. 44, n. 3, p. 453-460, 2014.

CAMPOS, M. K. F. et al. Drought tolerance and antioxidant enzymatic activity in transgenic "Swingle" citrumelo plants over-accumulating proline. Environmental and Experimental Botany, v. 72, n. 2, p. 242-250, 2011.
ESTEVES, S.; SUZUKI, M. S. Efeito da salinidade sobre as plantas. Oecologia Brasiliensis, v. 12, n. 4, p. 662-679, 2008.

GIANNOPOLITIS, C. N.; RIES, S. K. Superoxide dismutases: I. Occurrence in higher plants. Plant Physiology, v. 59, n. 2, p. 309-314, 1977.

GILL, S. S.; TUTEJA, N. Reactive oxygen species and antioxidant machinery in abiotic stress tolerance in crop plants. Plant Physiology and Biochemistry, v. 48, n. 12, p. 909-930, 2010.

HAMMERSCHMIDT, R.; NUCKLES, E. M.; KUC, J. Association of enhanced peroxidase activity with induced systemic resistance of cucumber to Colletotrichum lagenarium. Physiological Plant Pathology, v. 20, n. 1, p. 73-82, 1982.

HAVIR, E. A.; MCHALE, N. A. Biochemical and developmental characterization of multiple forms of catalase in tobacco leaves. Plant Physiology, v. 84, n. 2, p. 450-455, 1987.

HUSEYNOVA, I. M. Photosynthetic characteristics and enzymatic antioxidant capacity of leaves from wheat cultivars exposed to drought. Biochimica et Biophysica Acta Bioenergetics, v. 1817, n. 8, p. 1516-1523, 2012.

JIN, R. et al. Physiological changes of purslane (Portulaca oleracea L.) after progressive drought stress and rehydration. Scientia Horticulturae, v. 194, n. 10, p. 215 $221,2015$.

KUMAR, M. S. S. et al. Plant physiology and biochemistry role of phytosterols in drought stress tolerance in rice. Plant Physiology and Biochemistry, v. 96, n. 11, p. 8389, 2015.

LICHTENTHALER, H. K.; BUSCHMANN, C. Chlorophylls and carotenoids: measurement and characterization by UV-VIS spectroscopy. In: WROLSTAD, R. E. et al. Current protocols in food analytical chemistry. Hoboken: John Wiley \& Sons Inc., 2001. p. 1.2.1-1.2.13.

LIU, X.; CHAN, Z. Application of potassium polyacrylate increases soil water status and improves growth of bermudagrass (Cynodon dactylon) under drought stress condition. Scientia Horticulturae, v. 197, n. 12, p. 705711, 2015.

MAIA, J. M. et al. Atividade de enzimas antioxidantes e inibição do crescimento radicular de feijão caupi sob diferentes níveis de salinidade. Acta Botanica Brasilica, v. 26, n. 2, p. 342-349, 2012.

QUADROS, P. D. et al. Desempenho agronômico a campo de híbridos de milho inoculados com Azospirillum. Revista Ceres, v. 61, n. 2, p. 209-218, 2014. 
ROSA, S. D. V. F. et al. Enzimas removedoras de radicais livres e proteínas Lea associadas à tolerância de sementes de milho à alta temperatura de secagem. Revista Brasileira de Sementes, v. 27, n. 2, p. 91-101, 2005.

SHARMA, P. et al. Reactive oxygen species, oxidative damage, and antioxidative defense mechanism in plants under stressful conditions. Journal of Botany, v. 2012, n. 1, p. 1-26, 2012.

SHI, H. et al. Analysis of natural variation in bermudagrass (Cymodon dactylon) reveals physiological responses underlying drought tolerance. PlosOne, v. 7, n. 12, p. e53422, 2012.

STREIT, N. M. et al. As clorofilas. Ciência Rural, v. 35, n. 3, p. 748-755, 2005.

TAIZ, L.; ZEIGER, E. Fisiologia vegetal. Porto Alegre: Artemed, 2013.

TALAAT, N. B.; SHAWKY, B. T.; IBRAHIM, A. S. Alleviation of drought-induced oxidative stress in maize (Zea mays L.) plants by dual application of 24-epibrassinolide and spermine. Environmental and Experimental Botany, v. 113, n. 5, p. 47-58, 2015.

UZILDAY, B. et al. Comparison of ROS formation and antioxidant enzymes in Cleome gynandra $\left(\mathrm{C}_{4}\right)$ and Cleome spinosa $\left(\mathrm{C}_{3}\right)$ under drought stress. Plant Science, v. 182, n. 1 , p. 59-70, 2012.

ZAKIKHANI, H. et al. Influence of diazothophic bacteria on antioxidant enzymes and some biochemical characteristics of soybean subjected to water stress. Journal of Integrative Agriculture, v. 11, n. 11, p. 18281835, 2012.

ZHOU, Y.; LAMBRIDES, C. J.; FUKAI, S. Drought resistance of bermudagrass (Cynodon spp.) ecotypes collected from different climatic zones. Environmental and Experimental Botany, v. 85, n. 1, p. 22-29, 2013. 